\title{
Zinc Finger CCCH Domain-Containing Protein 7B
}

National Cancer Institute

\section{Source}

National Cancer Institute. Zinc Finger CCCH Domain-Containing Protein 7B. NCI

Thesaurus. Code C111982.

Zinc finger CCCH domain-containing protein 7B (993 aa, $112 \mathrm{kDa}$ ) is encoded by the human ZC3H7B gene. This protein plays a role in binding to rotavirus protein NSP3. 